Abstracta Iranica Abstracta Iranica

Revue bibliographique pour le domaine irano-aryen

Volume 25 | 2004

Comptes rendus des publications de 2002

\title{
« Nationalism, Politics, and the Development of Archaeology in Iran ». AJA 105, (2001), pp. 51-76.
}

\section{Rudi Matthee}

\section{Q OpenEdition \\ 12 Journals}

\section{Édition électronique}

URL : http://journals.openedition.org/abstractairanica/4044

ISSN : 1961-960X

\section{Éditeur :}

CNRS (UMR 7528 Mondes iraniens et indiens), Éditions de l'IFRI

Édition imprimée

Date de publication : 15 mai 2004

ISSN : 0240-8910

\section{Référence électronique}

Rudi Matthee, « « Nationalism, Politics, and the Development of Archaeology in Iran ». AJA 105, (2001) pp. 51-76. », Abstracta Iranica [En ligne], Volume 25 | 2004, document 12, mis en ligne le 15 mars 2006, consulté le 25 septembre 2020. URL : http://journals.openedition.org/abstractairanica/4044

Ce document a été généré automatiquement le 25 septembre 2020.

Tous droits réservés 


\title{
« Nationalism, Politics, and the Development of Archaeology in Iran ». AJA 105, (2001), pp. 51-76.
}

\author{
Rudi Matthee
}

1 This is an excellent, wide-ranging article on the relationship between archeology and nationalism in modern Iran. The author discusses the history of archeology in Iran from its beginnings in the 19th century until the current Islamic Republic. An initial period of mostly French activities gave way to nationalist accusations of foreign looting of Iran's historical riches, and came to an end in 1927 when the Iranians withdrew permits. The reign of Reza Shah, marked by a focus on the greatness of pre-Islamic, Zoroastrian Iran, saw a spate of activities and institutions related to the preservation of the country's patrimony, including the founding of the first archeological museum, and the establishment of a Society of National Heritage and an Antiquities Service. The Americans took over from the French, with Arthur Upham Pope playing an important role in promoting archeology as a nationalist endeavor. Archeology in the service of national grandeur continued unabated in the reign of Mohammad Reza Pahlavi, who was wont to invoke pre-Islamic symbolism even more than his father, causing the "explosive phase" of Iranian archeology. The first years of the Revolution were bad for pre-Islamic archeology, the author notes, adding that little of the rhetoric was backed up by deeds. As of the mid-1980 a new burst of activities can be seen, leading to the foundations of new centers and journals, the exploration of news sites, with European and even American cooperation. Nationalism is back, too, though the latest trend shuns the habitual conspiracy theories in favor of a search for internal causes for the decline of greatness that was ancient Iran. 
INDEX

Thèmes : 1.3. Ouvrages généraux, histoire de la discipline

\section{AUTEURS}

RUDI MATTHEE

University of Delaware 